\title{
Optymalizacja prętowych powłok walcowych za pomocą metody analogii potencjału energetycznego
}

\author{
Kajetan Sadowski \\ e-mail: kajetan.sadowski@pwr.edu.pl \\ Zakład konstrukcji i budownictwa ogólnego, \\ Wydziat Architektury Politechniki Wrocławskiej
}

\begin{abstract}
Streszczenie: Przestrzenne konstrukcje prętowe nazywane często strukturami przestrzennymi znalazły szerokie zastosowanie w świecie, szczególnie zaś w przekryciach obiektów o dużych rozpiętościach. Projektowanie obiektów w których znajdują zastosowanie prętowe struktury przestrzenne o skomplikowanej geometrii jej często poprzedzane licznymi badaniami teoretycznymi i modelowymi. Jednym z etapów projektowania, istotnym z punktu widzenia optymalizacji geometrycznej struktury jest wybór odpowiedniej metody wyznaczania jej morfologii. Opisując zjawiska zachodzące w naturze oraz sposób ich adaptacji do procesu projektowania architektoniczno-konstrukcyjnego autor przedstawia wyniki zastosowania metody analogii potencjałów energetycznych. Inspirację opracowania tej metody stanowi prawo Coulomba - przyjmując, że węzły dowolnej siatki przestrzennej są ładunkami elektrycznymi o ściśle określonych wartościach można otrzymać układ geometryczny w którym wszystkie elementy wzajemnie na siebie oddziałują. Ładunki przyjmą pozycje w przestrzenni dla których suma wzajemnych oddziaływań między nimi będzie najmniejsza. Będzie to układ najkorzystniejszy energetycznie.

W niniejszej pracy przedstawiono rezultaty optymalizacji wykonanych z pomocą modeli i symulacji cyfrowych opracowanych przez autora, poddanych następnie uproszczonym analizom statycznym. Wyniki pokazano za pomocą zaproponowanych przez autora wskaźników efektywności.
\end{abstract}

Słowa kluczowe: Przestrzenne konstrukcje prętowe, optymalizacja, powłoki walcowe

\section{Wstęp}

Zagadnienie poszukiwania równomiernego rozkładu w przestrzeni naładowanych potencjałem elektrycznym cząsteczek traktowanych, jako węzły struktury krystalicznej pojawia się w literaturze od lat ' 70 ubiegłego wieku. Założenie, że ich rozkład na powierzchni sfery, charakteryzujący się osiągnięciem minimum sumy energii potencjalnej pomiędzy nimi, nosi znamiona układu symetrycznego potwierdzali m.in.: Knop \& Smith (1977), Ashby \& Brittin (1986), Wille (1986), Frickel i Bronck (1987), Weinrach, Carter, Bennet \& McDowell (1990), Erber \& Hockey (1991), Edmundson $(1992,1993)$. Stwierdzali oni w optymalizowanych układach występowanie różnych grupy przestrzennych symetrii [1], [3]. Szczególnie J. R. Edmundson już w 1992 r. [2] przedstawił uzyskane za pomocą napisanego w Fortranie oprogramowania i obliczone na komputerze IBM 286 wyniki optymalizacji układów złożonych od 4 do 100 ładunków podając obliczoną dla niego minimalną energię potencjalną.

\section{Algorytm obliczeniowy}

Ładunki elektryczne zachowują się zgodnie z prawem Coulomba wyrażoną poniższym wzorem: 


$$
F^{1}=k \frac{\left|q_{1} q_{2}\right|}{r^{2}}
$$

gdzie $k$ jest tzw. współczynnikiem proporcjonalności wyrażanym w układzie SI przez:

$$
k=\frac{1}{4 \pi}
$$

gdzie $\varepsilon$ oznacza przenikalność elektryczną ośrodka. Na potrzeby prezentowanych badań przyjmowano ją jako stałą, niezależną od innych warunków.

Przyjmijmy, że węzłem dowolnej siatki $W_{1}$ przestrzennej jest ładunek elektryczny o wartości $q$ zlokalizowany w przestrzeni trójwymiarowej i opisany współrzędnymi $p x 1, p y 1, p z 1$. W przypadku, gdy w jego sąsiedztwie znajdzie się inny węzeł $W_{2}$ będą one na siebie oddziaływać siłą o wartości $F^{1}$. Ponieważ przyjmujemy, że wartości ładunków w obu węzłach są sobie równe, a wartość $k$ także jest zawsze stała, to możemy zdefiniować parametr wartości ładunku $Q^{1}$, który będzie wynosił:

$$
Q^{1}=q_{1}^{1} \times q_{2}^{1}
$$

a siła oddziaływania $F^{1}$ będzie miała wtedy wartość:

$$
F^{1}=\frac{Q^{1}}{d}
$$

gdzie $d=r^{2}$.

Uwzględniając położenie węzłów $W_{1}$ i $W_{2}$ w przestrzeni oraz zakładając, że $Q^{1}=1$, siła oddziaływania pomiędzy nimi będzie równa:

$$
F_{1-2}^{1}=1 / \sqrt{\left(p_{2}-p_{1}\right)+\left(p_{2}-p_{1}\right)+\left(p_{2}-p_{1}\right)}
$$

gdzie $p x_{i^{\prime}} p y_{i^{\prime}} p z_{i}$ oznaczają współrzędne $x, y, z$ węzła $W_{i}$

Siła $F^{7}$ będzie wywoływać przesunięcie każdego z węzłów o odległość $L^{1}$. W celu uproszczenia obliczeń i przy założeniu, że siła nie wywołuje stałej prędkości przyjęto założenie, że:

$$
L^{1}=F^{1}
$$

W układzie złożonym z określonej liczby $n$ węzłów $W_{i^{\prime}}$ gdzie i oddziaływania, przy $i \in\langle 1 ; n\rangle$, będą zachodzić wzajemnie pomiędzy wszystkimi węzłami. Oznacza to, że siła $F^{1}{ }_{w m}$ oddziaływująca na węzeł $W_{m}$ będzie sumą wszystkich sił odpychających, jakie zachodzą pomiędzy tym węzłem, a wszystkimi pozostałymi:

$$
F^{1}{ }_{m}=\sum_{i \rightarrow n, i \neq m} F_{W(m-i)}^{1}
$$

a przesunięcie $L^{1}{ }_{W m}$ tego węzła będzie się równać:

$$
L_{W h}^{1}=F_{\text {tw }}^{1}
$$

Przesunięcia wszystkich $n$ węzłów można opisać wzorem:

$$
L_{W}^{1}=\sum_{i \rightarrow n, i \neq m} L_{W(m-i)}^{1} \quad \text { gdzie } \mathrm{m} \in<1 ; \mathrm{n}>
$$


W ten sposób uzyskujemy w trakcie jednej iteracji określone przesunięcia wszystkich węzłów. Kolejna iteracja powoduje kolejne przesunięcie wszystkich węzłów itd. Zupełnie swobodne węzły będą się oddalać od siebie w nieskończoność, aż siła $F^{1}$ oddziaływania pomiędzy nimi spadnie do zera. W przypadku jednak, gdy uniemożliwimy im wydostanie się pewnej określonej przestrzeni siły oddziaływania pomiędzy nimi będą cały czas się pojawiać. Jednakże cały układ będzie dążył do stanu w którym jego energia potencjalna będzie najmniejsza, a przesunięcia będą dążyć do zera. W układzie zamkniętym będzie to oznaczać osiągnięcie lokalnego minimum. Stan w którym układ osiągnie minimum energii potencjalnej będzie stanem równowagi, który można opisać wzorem:

$$
F \longrightarrow F_{\min } \Leftrightarrow \sum_{m} F^{1}{ }_{W} \longrightarrow 0 \text { gdzie } \mathrm{m} \in<1 ; \mathrm{n}>
$$

\section{Statyczne kryteria analizy porównawczej}

Otrzymane za pomocą metody analogii potencjałów energetycznych modele badawcze zostały poddane uproszczonym analizom statycznych, których celem było sprawdzenie ich właściwości konstrukcyjnych. Każdorazowo zestawiono wyniki wartości naprężeń normalnych w wybranych charakterystycznych elementach struktury. Dodatkowo, aby dać pełen obraz wytężenia wszystkich prętów autor wprowadził propozycję zastosowania wskaźników:

Zaproponowano wskaźnik:

Wskaźnik Sumy Naprężeń Ekstremalnych (WSNE)

Stanowi on sumę wartości bezwzględnych naprężeń normalnych maksymalnych i minimalnych występujących we wszystkich prętach struktury i jest stosowany w modelach o węzłach sztywnych.

$$
W S N E=\sum_{i=1}^{n}\left(\left|S \max _{i}\right|+\left|S \min _{i}\right|\right)
$$

gdzie Smax ${ }_{i}$ oznacza wartość naprężeń normalnych maksymalnych w pręcie, $S_{m i n}$ oznacza wartość naprężeń normalnych minimalnych w pręcie a $n$ - ilość prętów w strukturze.

\section{Wyniki symulacji dla płaskich struktur dwuwarstwowych}

Powierzchnia walcowa należy do podstawowych form wykorzystywanych podczas projektowania przestrzennych struktur prętowych. Oddziaływujące na siebie węzły będą mogły się poruszać jedynie po powierzchni walcowej wyrażonej wzorem $x^{2}+y^{2}=r^{2} z$ zastrzeżeniem, że współrzędna piz nie może być mniejsza niż zadeklarowana wartość, tak aby ograniczyć ruch jedynie do preferowanego wycinka okręgu (rys. 1).

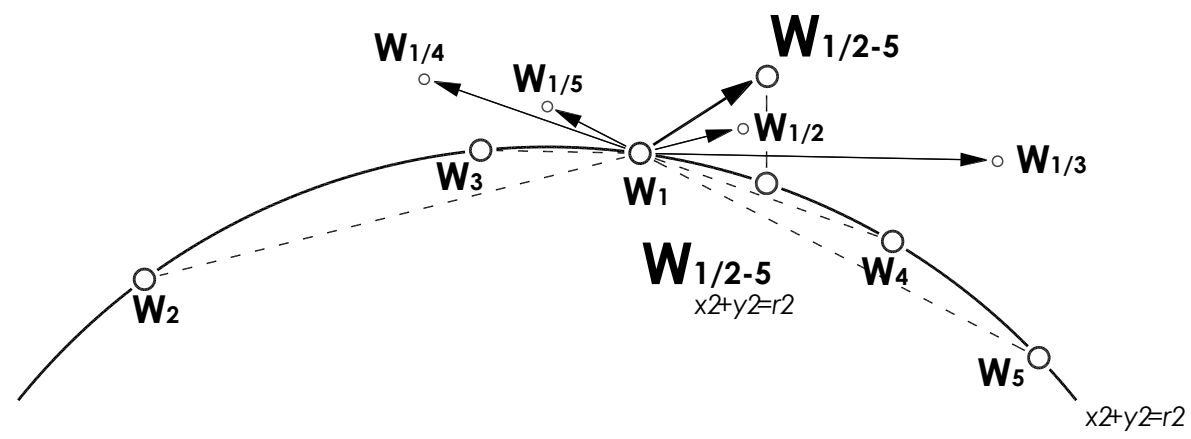

Ryc. 1. Węzeł $W_{1}$ i oddziaływujące na niego węzły $W_{2}-W_{5}$. 
Określenie lokalizacji wypadkowego węzła $\mathrm{W}_{1 / 2-5}$ na powierzchni wycinka łuku.

Poniżej zaprezentowane są wyniki symulacji i uproszczonej analizy statycznej dla wybranych struktur o kształcie powłoki walcowej o liczbie modułów $13 \times 13$, wymiarach w rzucie $10 \mathrm{~m} \times 9,32 \mathrm{~m}$, strzałce wysokości $2 \mathrm{~m}$. W celu umożliwienia wykonania analizy porównawczej na podstawie otrzymanych wyników przyjęto, że wszystkie modele badawcze są wykonane $z$ elementów tego samego rodzaju (pręty stalowe o przekroju kwadratowym $50 \times 50 \times 4$ mm łączone w sztywnych węzłach) oraz, że są poddane takiemu samemu obciążeniu jednostkowemu w każdym węźle struktury o wartości $1 \mathrm{kN}$.

Przyjęto zmienną wartość ładunków $Q^{1}$ równą 0, 100, 200, 300, 400 jednostek. Dodatkowo zablokowano możliwość przesuwania się węzłów brzegowych.

Tabela 1. Wynik optymalizacji dla siły $\mathrm{Q} 1=0 \mathrm{j}$.

\begin{tabular}{|c|c|c|}
\hline & $\begin{array}{l}\text { Maksymalne naprężenia normalne } \\
\text { w strefie podporowej* [MPa] }\end{array}$ & $\begin{array}{c}\text { Maksymalne naprężenia normalne w środku roz- } \\
\text { piętości* [MPa] }\end{array}$ \\
\hline & WARIANT 1 & Q1 = $0 \mathrm{j}$. \\
\hline 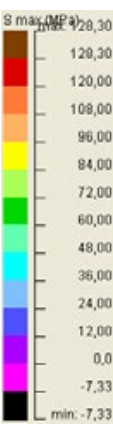 & A & $4^{4^{4^{6}}}$ \\
\hline \multirow[t]{2}{*}{ Skala } & Rzut & Perspektywa \\
\hline & 126,25 & 83,36 \\
\hline \multicolumn{2}{|c|}{ Wskaźnik Sumy Naprężeń Ekstremalnych WSNE } & $73757 \mathrm{MPa}$ \\
\hline
\end{tabular}

Tabela 2. Wynik optymalizacji dla siły $\mathrm{Q} 1=100 \mathrm{j}$.

\section{WARIANT 2}

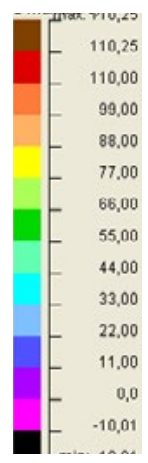

Skala

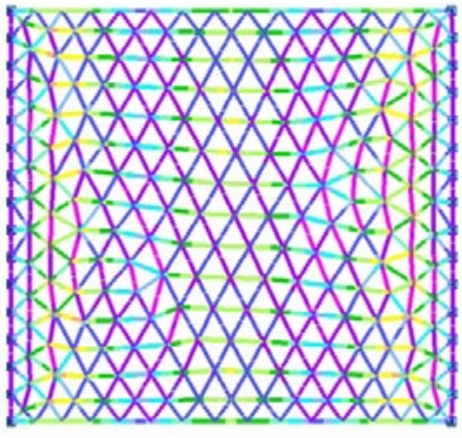

Rzut

95,89

Wskaźnik Sumy Naprężeń Ekstremalnych WSNE
$Q^{1}=100 j$.

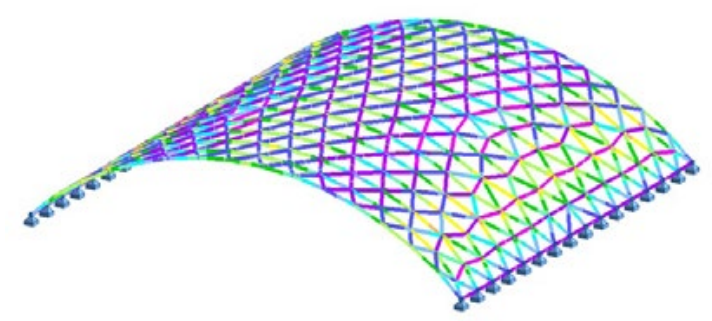

Perspektywa

76,38

$66289 \mathrm{MPa}$ 
Tabela 3. Wynik optymalizacji dla siły $\mathrm{Q} 1=200 \mathrm{j}$.

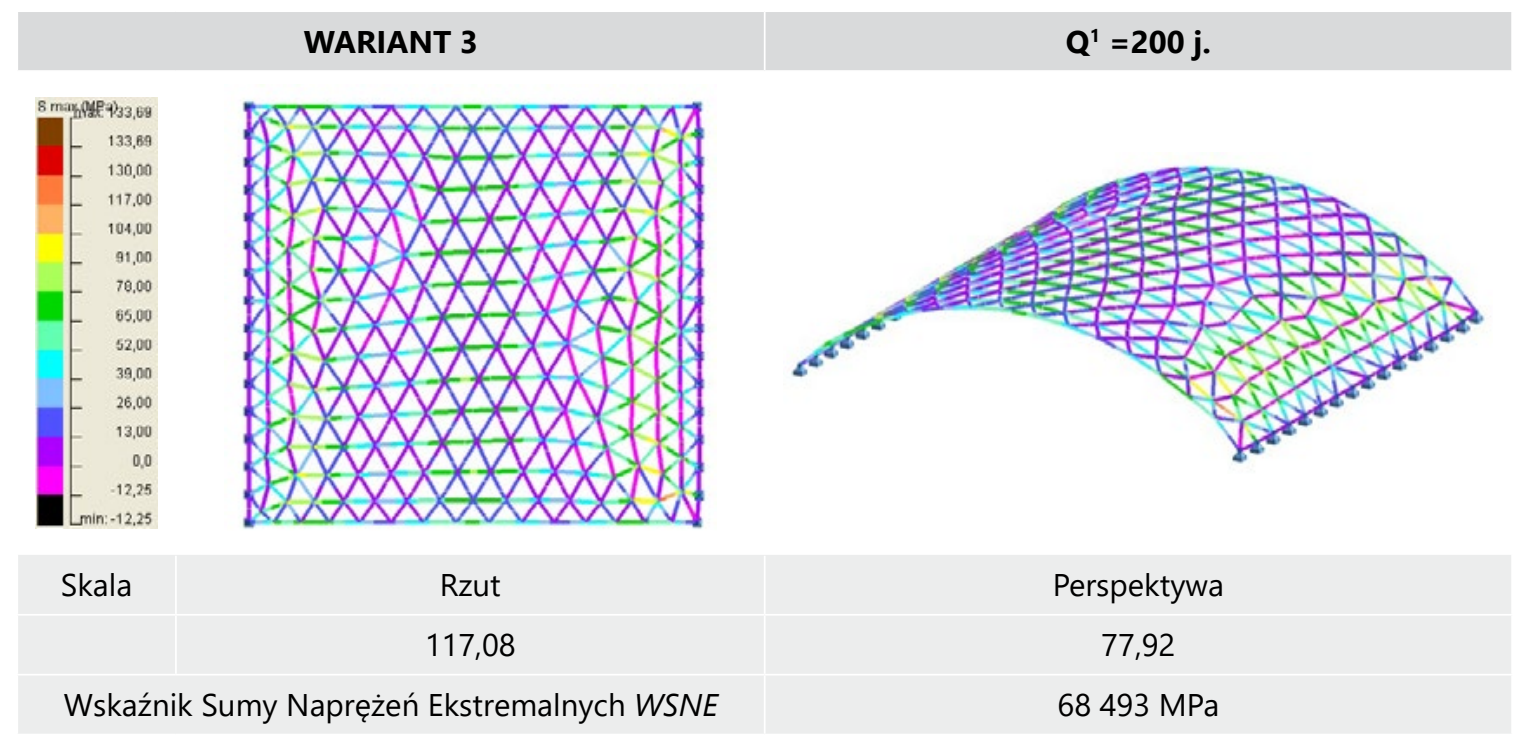

Tabela 4. Wynik optymalizacji dla siły $\mathrm{Q} 1=240 \mathrm{j}$.

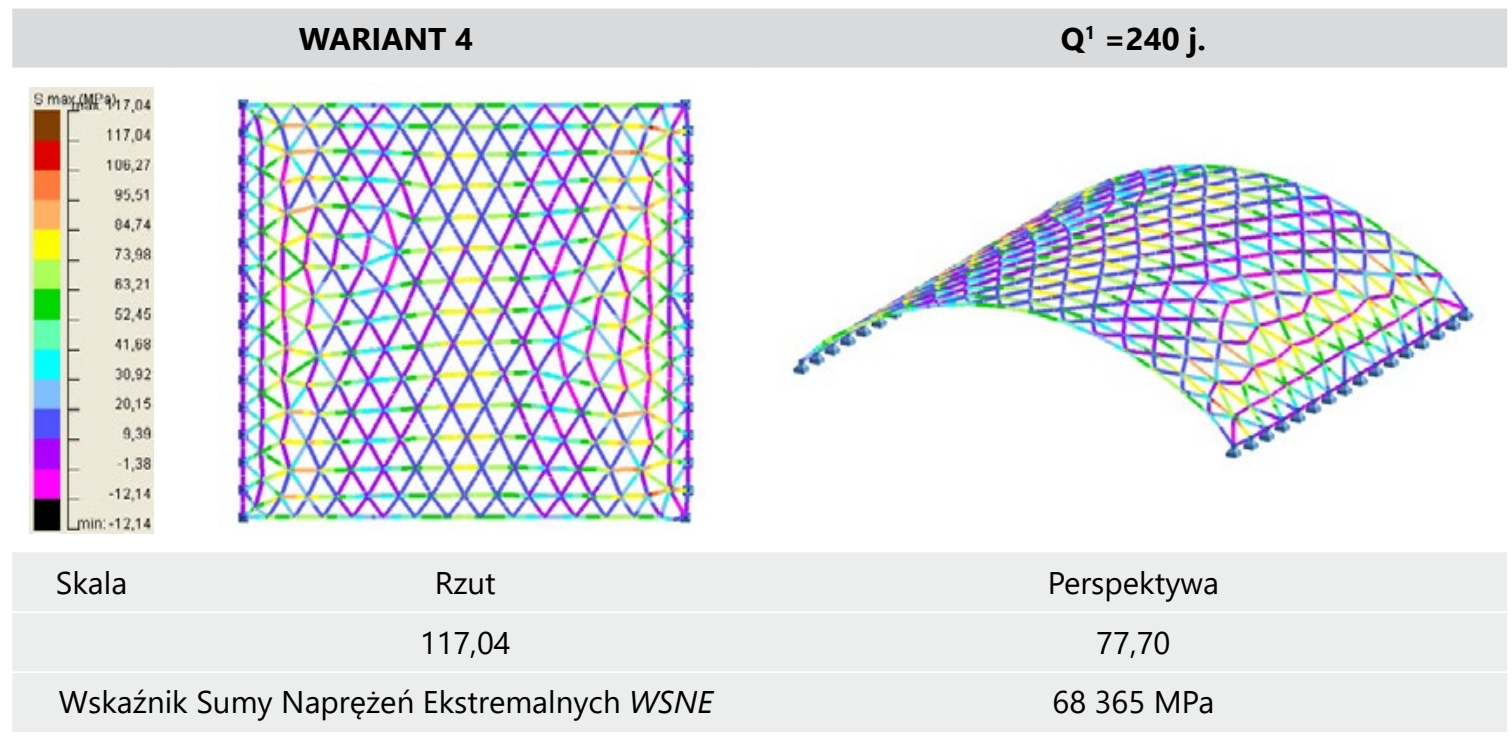


Tabela 5. Tabela 2: Wynik optymalizacji dla siły $\mathrm{Q} 1=300 \mathrm{j}$.

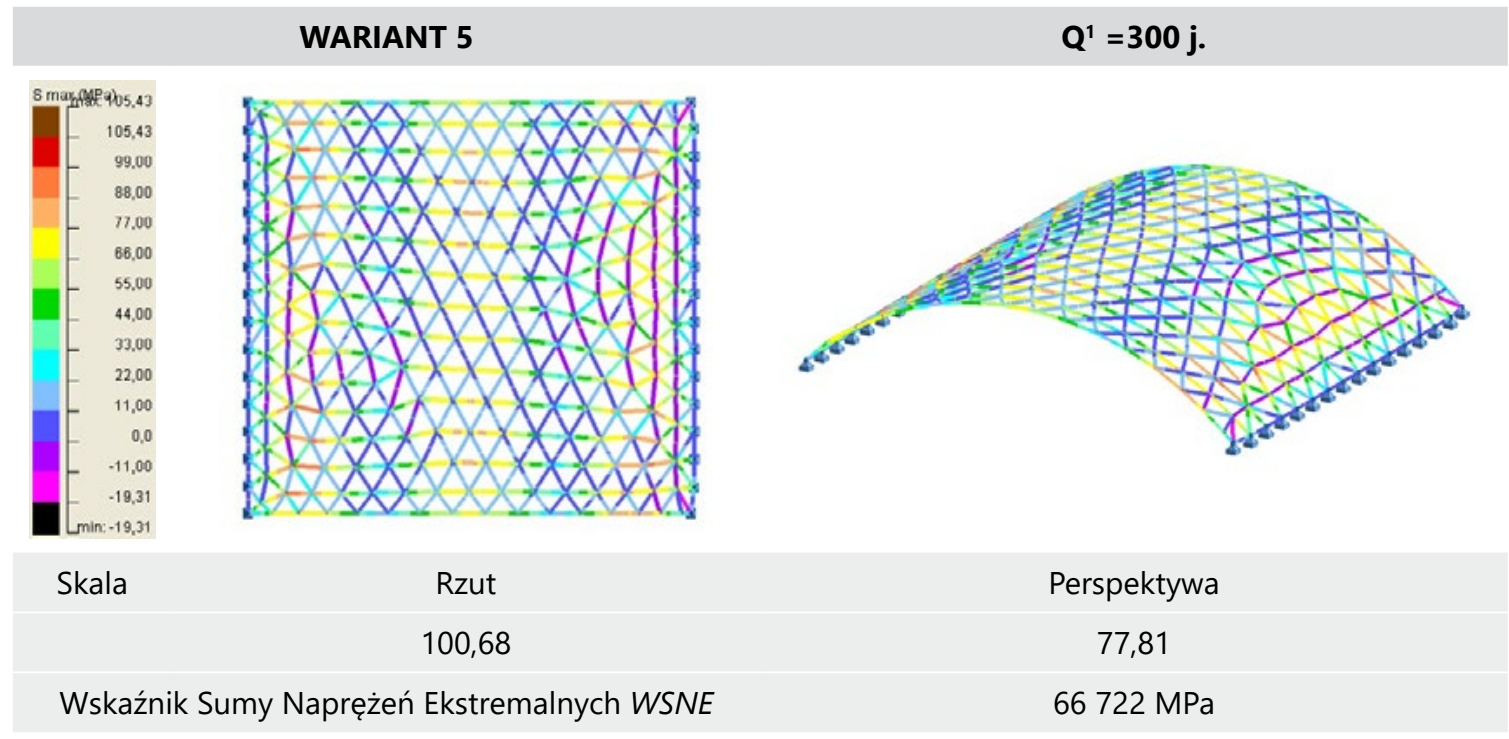

\section{Podsumowanie}

Poniżej przedstawiono wykres ujmujący ogólne tendencje właściwości badanych modeli optymalizowanych metodą analogii potencjałów energetycznych. Na osi odciętych zawarto przyjęte wartości zmiennych optymalizacyjnych, a rzędnych uzyskane wartości współczynnika WSNE.

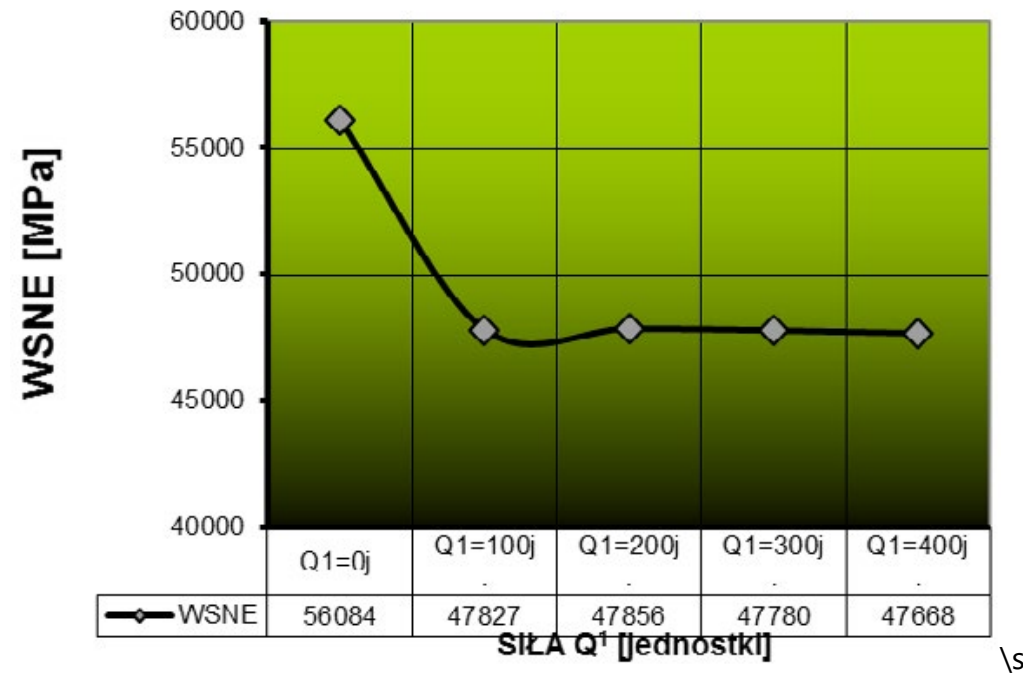

Ryc. 2. Wartości wskaźnika WSNE dla struktury Barrel_SPRT_all_FRC_all_ BLOK_y w zależności od przyjętych wartości zmiennych decyzyjnych. Liczba modułów: 15

Wyniki analiz optymalizacyjnych dla powyżej zaprezentowanych typów konstrukcji pozwalają stwierdzić, że metoda analogii potencjałów energetycznych przypadków przynosi zwiększenie efektywności konstrukcyjnej badanych struktur prętowych pod kątem wartości naprężeń normalnych w jej elementach opisanych wskaźnikami WSNE.

Analizy statyczne wykazały niezależną od stopnia podziału modelu podobną tendencję w kształtowaniu się wskaźnika WSNE. Dla badanej grupy ulegał on znacznej redukcji przy zastosowaniu metody optymalizacyjnej, jednak w obrębie samej korekty parametru $Q^{1}$ zmiany były nieznaczne i nie wykazywały wyraźnej tendencji 
kształtując się na podobnym poziomie. Procentową wartość minimalnego wskaźnika WSNE w stosunku do wskaźnika WSNE dla modelu wyjściowego osiągnięto na poziomie $85 \%$.

\title{
6. Piśmiennictwo
}

[1] Berezin A.A., 1985, An unexpected result in classical electrostatics. Nature, 315/1985, 104

[2] Edmundson J.R., 1992, The distribution of point charges on the surface of a sphere. ActaCryst, A48/1992, 60-69

[3] Nurmela K.J., 1997, Minimum-Energy Point Charge Configuration on a Curcular Disk. University of Technology, Digital Systems Laboratory, Series A: Research Reports nr 43, Helsinki, 1997.

[4] Sadowski K., 2004, Electric charges behaviour analogy applied to structural optymization of flat and barrel vaulted grids. X Lightweight structures in civil engineering. Local seminar of IASS Polish Chapter, Micro-Publisher 'Jan Obrębski' Wydawnictwo Naukowe, 2004, 217-219.

\section{Optimization of barrel vault surfaces using energetic potential method}

\begin{abstract}
Spatial structures are one of the most popular structural systems used to cover large spaces. Arrangement of the bars and nodes has a big influence on the distribution of forces inside the structure. Author was developing the method of dividing a surface which was called the energetic potential method. It is based on a natural process we know as the Coulomb Law. Using it we can create a self-optimizing structure where all of its nodes, mutually repulsing, are finally located in a similar distance to one another. Thanks to special computer program written by Author it was possible to generate a lot of structures with unique topology and after that could do a static analysis of them. After those it was found that some structures have a better ratio than popular structures so Author suppose that the method can have practical application in future [4].
\end{abstract}

Keywords: Space structures, optimization, barrel vaults 